\title{
Diets of Sheep, Angora Goats, Spanish Goats and White-tailed Deer under Excellent Range Conditions
}

\author{
F.C. BRYANT, M.M. KOTHMANN, AND L.B. MERRILL
}

\begin{abstract}
A study was initiated in August 1975 to illuminate the dietary interrelationships among four kinds of small ruminants on the Edwards Plateau of Texas. Sheep diets were dominated by grass followed by browse, goat diets were nearly equal in percent grass and browse, and deer spent most of their feeding time on browse followed by forbs. Livestock diets were not as high in forbs as expected, indicating that abundant grass due to excellent range condition may relieve livestock pressure on forbs, leaving more forbs for deer. Increased feeding time by deer on grass regrowth, after livestock were removed from the study area in July for a 4-month deferment, indicated that grazing systems were favorable to deer by providing regrowth forage. However, where livestock and deer graze in common, there are periods of competition even under excellent range conditions. These periods were fall and winter for browse, winter and early spring for forbs, and anytime immature grass was available. Relative to deer, sheep probably were most competitive for forbs and succulent grass, while goats, particularly the Spanish goats, were most competitive for browse. Similar annual trends for diets for all kinds of animals for all forage classes suggested competition was primarily for palatable green forage.
\end{abstract}

Common use grazing refers to the use of a range by more than one kind of animal during the same year. Its advantages lie in the abilities of different kinds of animals to more thoroughly cover the range and make efficient use of all forage species. Economic benefits have been derived from both game animals and livestock through common use grazing on the Edwards Plateau of Texas (Merrill and Young 1954; Huss and Allen 1969). This area supports one of the largest white-tailed deer (Odocoileus virginianus L.) concentrations in the world and is a major source of production from sheep, Spanish goats, and Angora goats. Consequently, knowledge of dietary interrelationships between livestock and deer is important to proper management of these rangelands.

Previous studies on the Edwards Plateau have provided valuable insight into grazing habits of several kinds of animals on Texas rangelands (McMahan 1964; Kothmann 1968; Malechek 1970; Taylor 1972; McCollum 1972). This research was designed to complement previous studies. The objectives were: (1) to measure the forage available for grazing at regular intervals throughout 1 year; (2) to determine the botanical composition of diets of sheep, Angora goats, Spanish goats, and

\footnotetext{
The authors are assistant professor, Range and Wildlife Management, Texas Tech University, and professors Department of Range Science, Texas A\&M University. At the time of this research, Bryant was research assistant, Range Science, Texas A\&M University.

Technical Article TA 14603 from the Texas Agricultural Experiment Station.

Manuscript received November 11, 1978
}

white-tailed deer at monthly intervals; (3) and to examine the dietary interrelationships among these four kinds of animals grazing on common range in excellent condition.

\section{Study Area}

The field research was conducted at the Texas A\&M University Agricultural Research Station located on the Edwards Plateau $45 \mathrm{~km}$ southeast of Sonora, Texas. Historically, this resource area was a grassland steppe, but since being invaded by numerous woody perennials, it now contains a botanical mosaic of grasses, forbs, and browse (Krebs 1972). Topography is rolling with steep breaks along some drainages. Soils are stony clays and clay loams. Precipitation averages $61 \mathrm{~cm}$ with peaks in May and September.

The study area was located within a 33-ha pasture which was in excellent condition (L.B. Merrill, per. comm.). From 1948 to 1970 , the pasture received light continuous grazing ( 16 animal units per 260 ha) with a 2:1:1 ratio of animal units of cattle, sheep, and Angora goats, respectively. In 1970, it was root-plowed and seeded with both introduced and native grass species. Stocking rate was subsequently incrcased to 40 animal units per 260 ha and the Merrill grazing system (4-3; 12:4 mo) was applied.

Due to the long rectangular nature of the pasture $(1.6 \times 0.4 \mathrm{~km})$, it was assumed that uniform grazing distribution could not be achieved by the different kinds of experimental animals used in the study. Consequently the study area was reduced to 8 ha by establishing a temporary enclosure on the west one-fourth of the pasture for $3 \mathrm{hr}$ on the days when the experimental animals were released to graze. This tactic restricted the experimental animals used in this study to the 8 ha enclosure during diet sampling but did not prevent grazing of the area by the resident animals on the Merrill grazing system.

Selection of the study area based on (1) amounts and variety of grasses and forbs and (2) amounts, growth form, and age class of two important browse species which were plateau oak (Quercus virginiana var. fusiformes (Small) Sarg.) and Vasey shin oak (Q. pungens var. vaseyana (Buckl.) C.H. Muller). Variety and abundance of the available forage generally allowed all animals to express dietary preferences. The browse stand consisted of 7 year regrowth following root plowing and had not been over-utilized to the extent that a browse line existed. Thus the browse stand had a relatively uniform growth pattern and was fairly productive of edible leaves and twigs. It was also within reach (less than $2 \mathrm{~m}$ tall) of all kinds of animals regardless of grazing behavior. This age class was also easier to quantify as to standing crop than were larger more mature trces.

\section{Materials and Methods}

Availability of herbaceous species and diets selected by the four kinds of animals were both sampled at monthly intervals for 1 year beginning August 20, 1975. The 2-day sampling for herbaceous species preceded diet sampling by no more than 4 days. Thus an 
estimate of herbaceous species available for consumption was obtained just prior to diet sampling.

Estimates of standing crop of grass and forb species were obtained using a modification of the technique proposed by Goebel et al. (1958) and modified by Durham and Kothmann (1977) and Bryant (1977). The area was sampled along randomly located transects by reading 100 plots $\left(.25 \mathrm{~m}^{2}\right)$ covered with a $10-\mathrm{cm}$ grid to estimate cover. In a separate sample each species was clipped to determine weight per unit of cover. The 100-plot sample size was sufficient as indicated by species: area curves (Oosting 1956).

All browse species were sampled for edible and total standing crop in August at the initiation of the study. Standing crop was estimated for plateau oak and Vasey shin oak again during November before frost, and in February before initiation of spring growth, and in May and July, 1976.

The sampling approach involved establishing the density and mean volume for each browse species and assuming these parameters were constant for 1 year. The oak densities were estimated using the corrected-point-distance technique of Laycock and Batcheler (1975), due to their aggregate growth pattern (i.e., clones). Densities of all other browse species were estimated using the point-centered quarter technique (Cottam and Curtis 1956). Regression equations were developed to predict the mean weight per plant using conical volume as the independent variable. Standing crop was estimated by multiplying density times weight per plant. A complete description of the technique was reported by Bryant and Kothmann (1979).

Diets of all four kinds of animals were sampled on 5 consecutive days each month. All study animals were fasted overnight prior to diet collections. Deer were grazed in the morning and livestock were grazed in the afternoon after an additional 6-hr fast. The four kinds of animals were treated similarly in that (1) all were maintained in a dry-lot, fed alfalfa hay during collection periods, and fed cottonseed cake and alfalfa hay between collection periods, (2) water and salt were always available, (3) all were fasted prior to each collection, (4) all were transported to and from the study area each collection day, and (5) all were allowed to graze for .75 to $1.0 \mathrm{hr}$ each day. However, livestock were released for a 72-hr grazing period prior to the initial collection day of each month and deer were not. This allowed at least the sheep and goats to become familar with changes in vegetation, as recommended by Langlands (1967).

Livestock diets were obtained from four each of Angora goats, Spanish goats, and sheep fitted with permanent esophageal cannulae described by Taylor and Bryant (1977). Due to losses, eight Angora goats, eleven Spanish goats, and nine sheep were used to collect diet samples during the study. Each sampling day, the extrusa samples were collected in screen-bottomed bags, thoroughly hand-mixed, and separated into two sub-samples. One was used for botanical and one for chemical analyses. Chemical analyses will be reported in another paper. The sub-samples for botanical analyses were composited by animals across days and by days across animals within each collection period. Botanical composition, based on percent of plant fragments, was determined for the three major forage classes (grass, forb, and browse) and for plant parts (leaf, stem, and head, or flower) within a forage class after Durham and Kothmann (1977).

Twenty wild-trapped white-tailed deer fawns were raised and trained following the guidelines of Reichert (1972). Of the 20, only two survived that adapted to the rigors of transporting and handling and could still be allowed free range of the study area without the confines of a leash (Fig. 1). At project initiation one fawn was 5 mo old while the other was 4 mo. Thus the study utilized two deer through their most critical life stage, weanling to yearling age (4 to 17 months). As an index to selection, the feeding minutes method was employed. The major limitations of this technique have been reported by Bjugstad et al. (1970). Feeding minutes has been found to overestimate browse and underestimate grass as diet constituents when compared with the esophageal fistula technique (Bryant 1977). Therefore, diet data from deer were excluded from statistical treatment.

Significant differences in the botanical composition of livestock diets were determined by analysis of variance. Differences in monthly and annual means were evaluated with Duncan's multiple range test

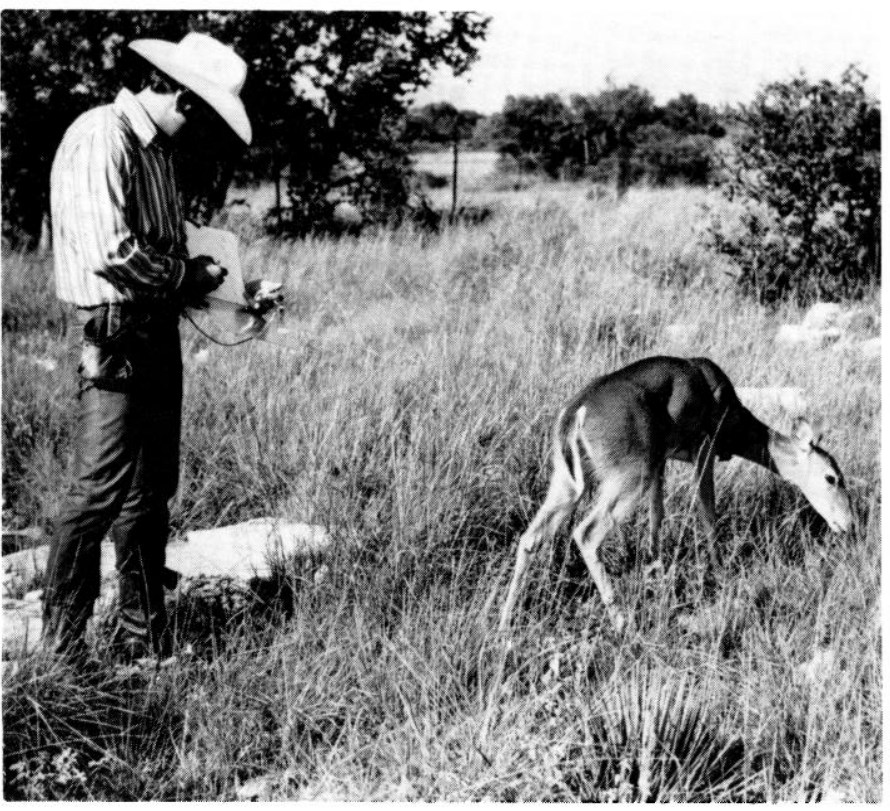

Fig. 1. The feeding minutes technique being used to determine the diet of whitetailed deer at the Sonora Research Station.

(Dixon and Massey 1969). Due to the unbalanced nature of the data, a computerized general linear models program was used in analysis of variance (Barr et al. 1976).

\section{Results and Discussion}

\section{Forage Availability}

Standing crop of all 3 forage classes declined from August to February due to utilization, leaf fall, and decomposition of mature forage (Fig. 2). Grass growth exceeded utilization in March, April, and July, while forb growth exceeded utilization in April, May, and July. Forb standing crop declined in June due to heat stress that dried up many of the succulent cool-season forbs. Grasses and forbs increased during July in response to 28 $\mathrm{cm}$ of rainfall received during the month, and because all livestock were removed on July 1, 1976, to allow the pasture 4 mo of rest. Standing crop of herbage and edible browse in July, 1976, did not reach levels measured in August 1975, following a spring deferment.

\section{Diet Composition Sheep}

Percent contribution of forage classes to the diets of sheep, averaged across 12 months, was highest for grass $(60 \%)$, followed by browse $(22 \%)$, and forbs (18\%) (Table 1). Kothmann (1968) reported sheep selected strikingly similar diets (55\% grasses, $28 \%$ browse, and $16 \%$ forbs) on poor condition range. However, on good condition range, he found forbs dominated sheep diets $(55 \%)$ and were important to winter diets. Availability ( $\mathrm{kg} / \mathrm{ha}$ ) of palatable forbs in this study was, except in winter, as high or higher than values reported on good condition pasture by Kothmann (1968), while variety of forbs was even greater. Identical techniques were used for botanical analysis of diet samples. Possibly, the increased availability and variety of grasses in this study encouraged sheep to select more grass than forbs. On the other hand, a dense grass cover may have reduced the accessibility of forbs. However, some of the discrepancy probably can be explained by a higher availability 

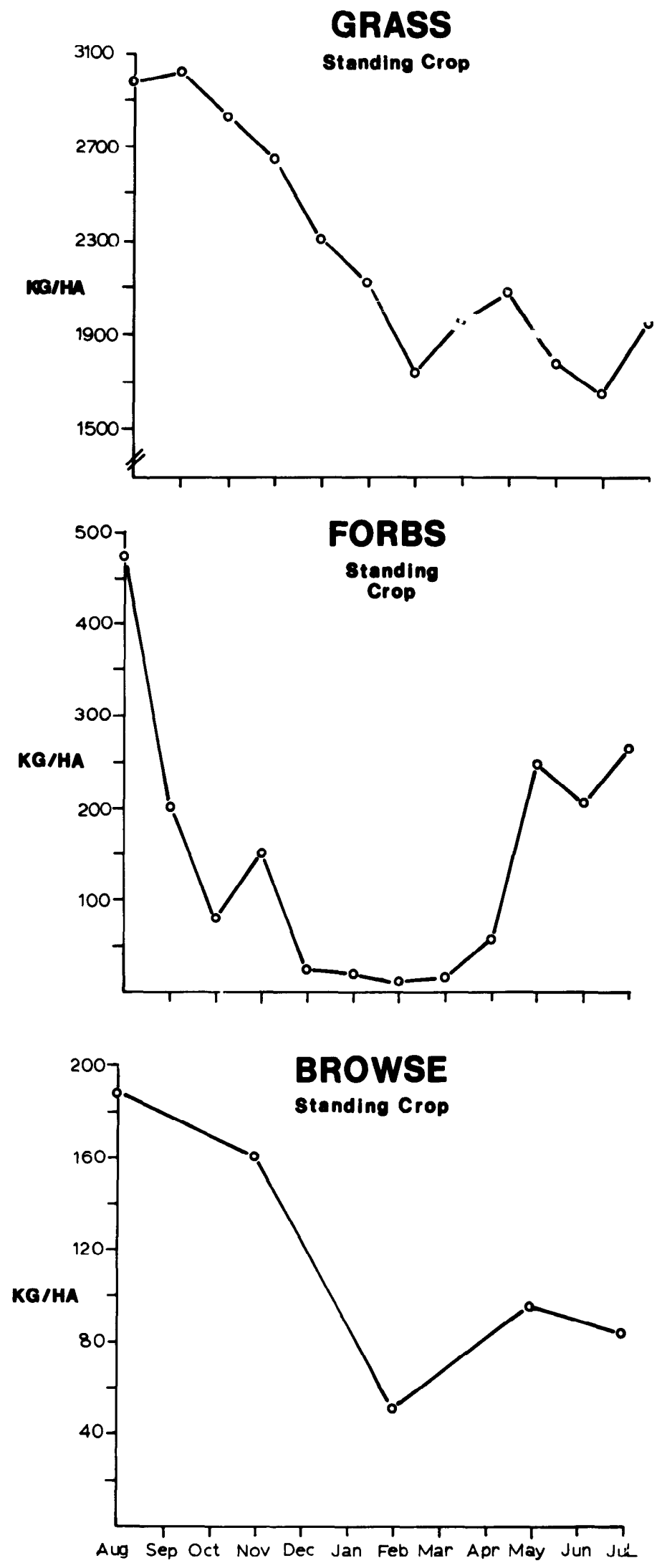

Fig. 2. Standing crop of grasses, forbs, and edible browse from August 1975 to July 1976, on the study area at the Sonora Research Station.

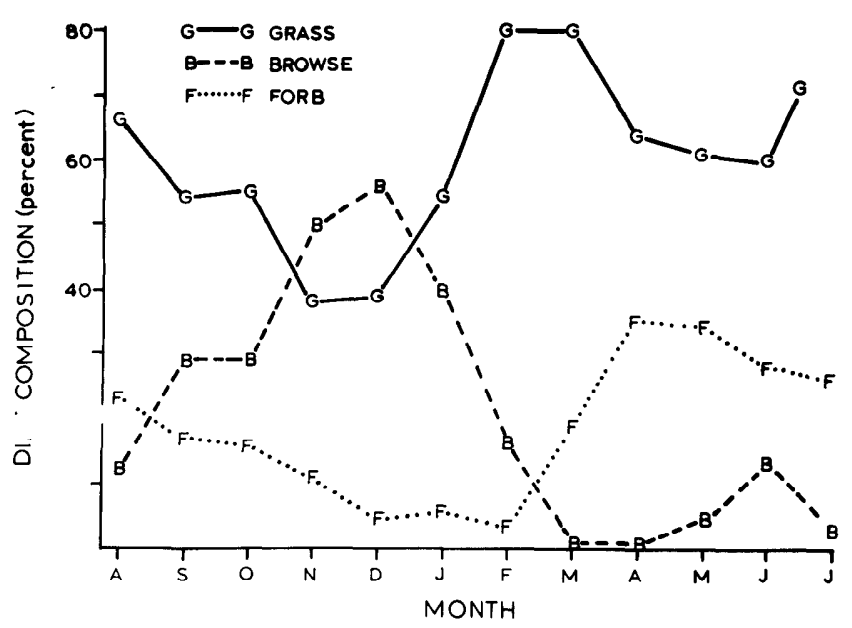

Fig. 3. Percentage of grass, forb, and browse fragments in sheep diets at monthly intervals throughout the year.

and selection of forbs during winter in Kothmann's study. Other researchers have also reported that forb use by sheep increased as forb availability increased (Cook et al. 1967; Buchanan et al. 1972).

Sheep in this study appeared to shift their diet among the forage classes as the seasons changed (Fig. 3). During the growing season, grasses and forbs dominated the diets. From August through December, when grasses and forbs were mature, browse began to replace the herbaceous components of the diet. The dietary proportion of browse peaked in November and December. Kothmann (1968) reported the peak percent of browse in sheep diets occurred in January on both good and poor condition ranges. In this study, sheep compensated for a shortage of browse in January by increasing their consumption of grass from 39 to $54 \%$.

Sheep were consistent in their use of grass. Percent grass in the diets did not differ significantly $(P>.05)$ for 10 of the 12 months. Grass appeared to provide the base for the diet while forbs were selected opportunistically. Percent forbs in the diets closely paralleled the trend for availability of forbs. Browse was selected primarily during periods when herbage was mature, even though herbage comprised more than $90 \%$ of the available forage. This assumption was supported by the increased percent of browse in sheep diets during the June heat stress period.

Leaf material comprised $96 \%$ of the sheep diets throughout the year (Table 1). Sheep utilized grass stems only in early fall and late spring while browse stems were consumed during winter. Dudzinski and Arnold (1973) reported leaf material in sheep diets was consistently greater than $93 \%$, while Kothmann (1968) observed sheep diets to consist of more than $86 \%$ leaf material.

Table 1. Mean annual diet composition (percent) for livestock and deer grazed on the Texas A\&M University Research Station at Sonora, Texas.

\begin{tabular}{lccccccc}
\hline & \multicolumn{3}{c}{ Forage class } & & \multicolumn{3}{c}{ Plant part } \\
\cline { 7 - 8 } Kind of animal & Grass & Browse & Forb & & Leaf & Stem & Flower \\
\hline Sheep & $60^{a}$ & $22^{a}$ & $18^{a}$ & & $96^{a}$ & $3^{a}$ & $1^{a}$ \\
Angora goats & $48^{b}$ & $40^{b}$ & $12^{b}$ & & $96^{a}$ & $3^{a}$ & $1^{a}$ \\
Spanish goats & $45^{c}$ & $42^{b}$ & $13^{b}$ & & $95^{a}$ & $4^{a}$ & $\mathrm{t}^{a}$ \\
White-tailed deer* & 8 & 61 & 31 & & - & - & -
\end{tabular}

${ }_{a b c}$ Means in the same column followed by the same letter are not significantly different $(P<.05)$.

* Deer were not included in mean separation. 


\section{Angora Goats}

Angora goat diets contained similar amounts of grass (48\%) and browse (40\%) (Table 1). Malechek (1970) reported similar annual means for grass and browse components (50 and 39\%, respectively) under light, continuous grazing. Annual trends reported by Malechek (1970) were remarkably similar to those found in this study. Angora goat diets from this study contained $12 \%$ forbs compared to $11 \%$ forbs reported by Malechek, even though drought conditions existed during Malechek's study and forbs were not as available. Further, McMahan (1964) noted tame Angora goats increased their use of forbs when grazed in an exclosure that contained large amounts of forbs. It appears, as with sheep, excellent condition range also reduces the impact Angora goats have on forbs. The high protein diet fed to the experimental animals while in confinement may be partly responsible. However, Regelin et al. (1977) found no difference in forage preferences of tame, free ranging mule deer than those fed protein supplements.

Percentages of grass and browse in the diets were relatively constant throughout the year (Fig. 4). Major deviations from the annual means occurred in December for grass, and December and July for browse. Angora goat diets tended to shift back and forth from grass to browse.

Forbs increased in Angora goat diets in the spring (Fig. 4). The percentage of dietary forbs was higher in spring than fall even though availability in both seasons was similar. Mature forbs were obviously not as palatable. Malechek (1970) also found more forbs in Angora goat diets during spring, however, he reported higher percentages of forbs in diets during autumn than found in this study.

Leaf material comprised $96 \%$ of Angora goat diets (Table 1), which agrees closely with Malechek (1970). The highest percent of stems in the diets $(7 \%)$ occurred during January and these were primarily grasses.

\section{Spanish Goats}

Grass in Spanish goat diets throughout the year was only slightly higher than browse with 45 and $42 \%$, respectively. In July, percent of grass in diets was significantly higher than for the lowest month, December (Fig. 5). Browse was significantly lower in July than December. Percent grass and browse in the diets did not differ significantly among the other 10 months. Forbs were a minor component of the diets except in spring and summer.

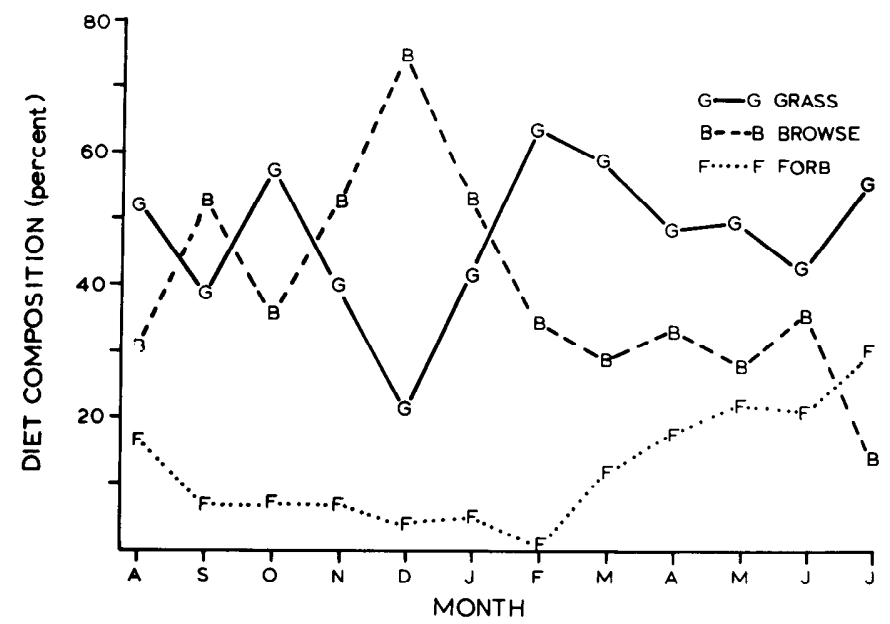

Fig. 4. Percentage of grass, forb, and browse fragments in Angora goat diets at monthly intervals throughout the year.

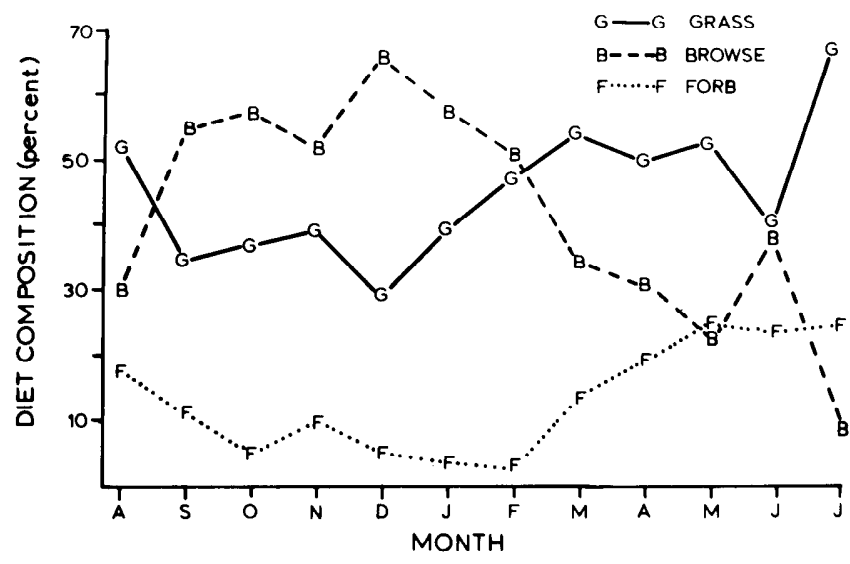

Fig. 5. Percentage of grass, forb, and browse fragments in Spanish goat diets at monthly intervals throughout the year.

In the fall as grass availability declined, Spanish goats continued to select consistently high percentages of grass. Forbs did not contribute significantly to the diets from October through February. Forbs increased in diets during spring in response to greater availability, while browse in diets declined. Browse was lowest in the diets in July when Spanish goats selected actively growing grasses.

Spanish goat diets contained 95\% leaf material (Table 1). Stem fragments were relatively constant in diets throughout the year for all forage classes. In May, $7 \%$ of Spanish goat diets was Texas cupgrass (Eriochloa sericea (Scheele) Munro) seedheads.

Deer

Overall, deer spent more time feeding on browse $(61 \%)$ than any other forage class (Table 1). Forbs were intermediate (31\%) while grasses were lowest $(8 \%)$. Deer consistently fed on browse and forbs. Except for July, grasses apparently were of little importance to them (Fig. 6).

Other researchers have reported similar findings on the importance of browse and forbs in deer diets, along with the seeming. unimportance of grass (McMahan 1964; Drawe 1968; Evcritt and Drawe 1974). In contrast, McCollum (1972)

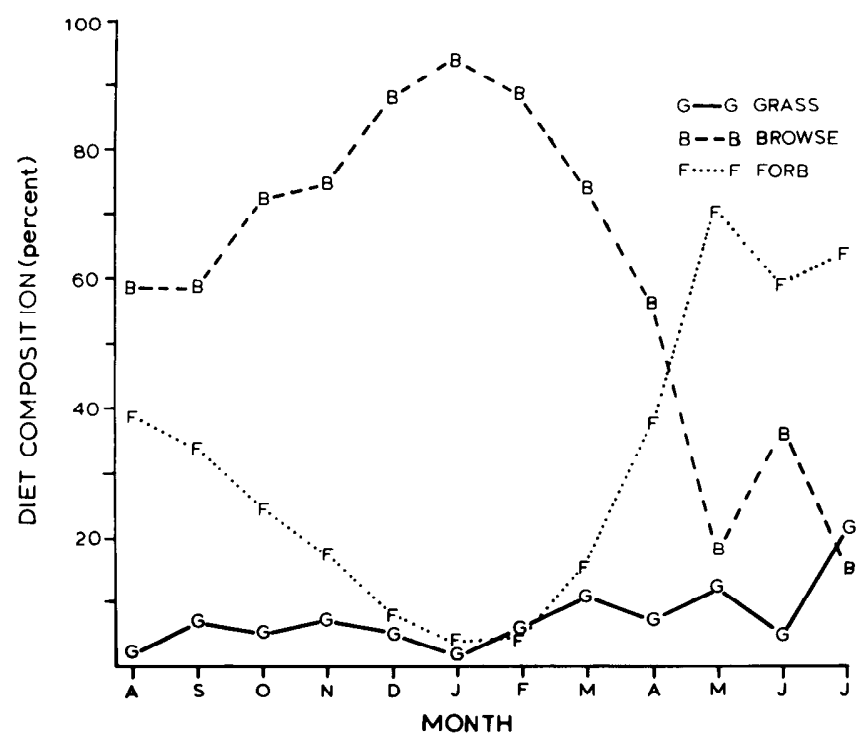

Fig. 6. Percentage of time deer fed on grass, forbs, and browse at monthly intervals throughout the year. 
found high use of grass by deer in winter and spring on the Edwards Plateau. In South Texas, deer used grass extensively only in winter (Drawe and Box 1968). Deer in this study were young and were not under nutritional stress. Older deer subjected to nutritional stress may in fact spend more time feeding on grass. However, since young animals require high protein levels (Ullrey et al. 1967) and grass is relatively low in protein (Fraps and Cory 1940), insignificant use of grass by young deer is nutritionally to their advantage.

The amount of time deer fed on forbs closely paralleled availability, especially during May, June, and July. Feeding minutes on browse was inversely related to availability, suggesting deer were forced to use browse rather than preferring it.

Deer diets responded to changes in grass availability only in July (Fig. 6). This was attributed to removal of livestock from the pasture in July and the regrowth of grasses. Deer did not have to compete with livestock for the nutritious grass regrowth available at that time.

Johnsongrass (Sorghum halepense (L.) Pers.), Texas wintergrass (Stipa leucotricha Trin. and Rupr.), and Carex spp. were the most important grass and grass-like species grazed by the deer during the study. Cane bluestem (Bothriochloa barbinodis var. barbinodis (Lag.) Herter) was important only in July when deer spent $8 \%$ of their feeding time on that species.

From August through October, Texas snoutbean (Rhynchosia texana Torr. and Gray), orange zexmenia (Zexmenia hispida H.B.K.), copperleaf (Acalypha lindheimeri Muell. Arg.), Texas virgins bower (Clematis drummondii Torr. and Gray), and Indianmallow (Abutilon incanum (Link.) Sweet) accounted for $80 \%$ of the total time deer spent grazing forbs. From November through March, primary forbs selected by deer were upright prairie-coneflower (rosettes) (Ratibida columnaris (Sims) D. Don.), Mexican sagewort (Artemisia ludoviciana var. mexicana (Willd.) Fern.), Texas virgins bower, and prickly lettuce (Lactuca serriola L.). From April through July, Texas snoutbean, Indianmallow, orange zexmenia, velvet bundleflower (Desmanthus velutinus Scheele), chickenthief mentzelia (Mentzelia oligosperma Nutt.), copperleaf, dayflower (Commelina angustifolia Michx.), and milkvetch (Astragalus spp.) made up $80 \%$ of the deer's forb grazing time. Deer selected from an average of 30 species of forbs per month, the highest number occurring in May (38 species).

Of all the previously mentioned forb species, only prickly lettuce, dayflower, and velvet bundleflower were similarly listed as important to deer in the studies of McMahan (1964) and McCullum (1972). Since McMahan (1964) did not report availability, it is difficult to judge the opportunity for selection afforded his deer. The important species listed in this study were unavailable in most, if not all, of the pastures sampled by McCollum (1972). Deer in this study were allowed a greater opportunity to express their preference for forbs than were deer in other studies on the Edwards Plateau.

Plateau oak dominated the deer's browsing time in most months (Fig. 6). A notable exception was in March when deer spent $41 \%$ of their total time feeding on Vasey shin oak. This corresponded to the time it was actively producing tender, new growth twigs. Vasey shin oak normally initiates new leaves in April and use was expected to be high (Malechek 1970). However, a freeze in late March killed new growth leaves of browse plants. Interestingly, decadent leaves of Texas persimmon (Diospyros texana Scheele) from the previous year's growth were highly selected in March, as deer spent $12 \%$ of their time on them. Sugar hackberry (Celtis laevigata Willd.) was relatively important in spring. In August, March, April, and July, decr selected from 9 to 10 different browse species. McCollum (1972) and McMahan (1964) also found deer to rely on oaks as their primary source of browse.

\section{Dietary Interrelationships \\ Grass}

All four kinds of animals exhibited similar trends for percentage of grass in their diets. Competition for grass was probably greatest between sheep and Angora goats since their diets were most similar with respect to percent grass. Diets of all four kinds of animals responded to both new growth and regrowth of grass as proportions increased in early spring and again in July. Therefore, it appears that competition was keen among livestock and particularly between livestock and deer when there were small amounts of high quality grass available. The competitive use of nutritious grass regrowth by cattle cannot be discounted because they are known to use large amounts of grass (Taylor 1972). However, their influence may be facilitative since they may remove mature growth thus making the regrowth more available. There was probably no competition among the four kinds of animals for dry grass because it was always abundant.

\section{Forbs}

The trends for forbs in diets and standing crop suggest competition was greatest in winter when forbs were scarce. Deer were particularly vulnerable during this period due to their apparent inability to use dry grass and to their high requirement for crude protein. This lack of winter forbs due to utilization and short term drought helps explain the poor antler development on yearling males harvested on the Sonora station the following autumn (Pat Reardon, per. comm.). Critical competition probably occurred in March as livestock grazed forbs to the extent that utilization apparently equaled net primary production. Later in spring, forbs increased in livestock and deer diets but availability also increased, suggesting competition was somewhat reduced compared with winter. Competition for mature forbs during late summer and fall was negligible since availability was high and forbs were only moderately important to diets of deer and livestock. Sheep appeared to be slightly more competitive with deer for forbs than were Angora or Spanish goats. Intensive management for deer suggests that sheep and goats could be restricted to small portions of the total deer range during this critical winter-early spring period to reduce their competition with deer. Future research should examine the economic practicality and possible trade-offs in sheep and goat management vs. deer management.

\section{Browse}

Trends of percent browse in diets were most similar among sheep and Angora goats, while trends for deer and Spanish goats were similar. All four kinds of animals competed for a limited quantity of edible browse in late autumn and early wintcr. In latc winter when availability of browse was lowest, livestock consumed less browse, shifting primarily to dry grass. Deer, however, did not shift from browse to dry grass in late winter. Thus, the high proportions of browse in livestock diets prior to late winter, coupled with even small proportions in late winter, may have created a severe competitive influence on deer by reducing the availability of a forage class they so highly depended upon. Spanish goats continued to select higher levels of browse later in winter than sheep or Angora goats. inaicating 
that Spanish goats may be more competitive with deer for edible browse during late winter. In addition, ongoing research at the Sonora station suggests Spanish goats may use more browse than Angora goats when pastures are in poor range condition (Charles A. Taylor, per. comm.).

\section{Conclusions}

These data indicate deer are favorably affected by proper grazing management which led to excellent range conditions on the study area. The ample grass availability may act to reduce the impact sheep and goats have on forbs, a forage class highly important to deer. Further, grazing systems increased the availability of grass regrowth to deer thus supplying a nutritious forage with reduced competition from livestock. It cannot be overlooked, however, that even though the pasture was in excellent condition, there were critical times of the year where competition occurred for certain forages. If deer are a primary management consideration, proper stocking of sheep and goats during critical times of the year on Texas ranges cannot be overemphasized.

While significant variations occurred among the diets of the four kinds of animals, the overall similarity in trends for the selection of grass, forbs, and browse was surprising. Perhaps the competition among kinds of animals can best be summarized in terms of competition for green forage. Species preferences were evident indicating that there would be a degree of complementarity.

\section{Literature Cited}

Barr, A.J., J.H. Goodnight, J.S. Sall, and J.T. Helwig. 1976. A user's guide to S.A.S. 76. SAS Institute Inc. Raleigh; N. Car. 329 p. Bjugstad, A.J., H.S. Crawford, and D.L. Neal. 1970. Determining forage consumption by direct observation of domestic grazing animals. In Range and Wildlife Habitat Evaluation-A Research Symposium. USDA Forest Serv. Misc. Pub. 1147. 220 p.

Bryant, F.C. 1977. Botanical and nutritive content in diets of sheep, Angora goats, Spanish goats and white-tailed deer grazing a common pasture. Ph.D. Diss., Texas A\&M Univ., College Station. 92 p.

Bryant, F.C., and M.M. Kothmann. 1978. Variability in predicting edible browse forage from crown volume. J. Range Manage. 32:144-146.

Buchanan, H., W.A. Laycock, and D.A. Price. 1972. Botanical and nutritive content of the summer diet of sheep on a tall forb range in southwestern Montana. J. Anim. Sci. 35:423-430.

Cook, C.W., L.E. Harris, and M.C. Young. 1967. Botanical and nutritive content of diets of cattle and sheep under single and common use on mountain ranges. J. Anim. Sci. 26: 1169-1174.

Cottam, G., and J.T. Curtis. 1956. The use of distance measures in phytosociological sampling. Ecology 37:451-460.

Dixon, W.J., and F.J. Massey. 1969. Introduction to statistical methods. McGraw-Hill Book Co. 637 p.
Drawe, D.L. 1968. Mid-summer diets of deer on the Welder Wildlife Refuge. J. Range Manage. 21:164-166.

Drawe, D.L., and T.W. Box. 1968. Forage ratings for deer and cattle on the Welder Wildlife Refuge. J. Range Manage. 21:225-228.

Dudzinski, M.L., and G.W. Arnold. 1973. Comparisons of diets of sheep and cattle grazing together on sown pastures on the southern tablelands of New South Wales by principal component analysis. Aust. J. Agr. Res. 24:899-912.

Durham, A.J., Jr., and M.M. Kothmann. 1977. Forage availability and cattle diets on the Texas coastal prairie. J. Range Manage. 30:103-106.

Everitt, J.H., and D.L. Drawe. 1974. Spring food habits of white-tailed deer in the south Texas plains. J. Range Manage. 27:15-20.

Fraps, G.S., and V.L. Cory. 1940. Composition and utilization of range vegetation of Sutton and Edwards counties. Tex. Agr. Exp. Sta. B-586. 33 p.

Goebel, C.J., L. Debano, and R.D. Lloyd. 1958. A new method of determining forage cover and production on desert shrub vegetation. J. Range Manage. 11:244-246.

Huss, D.L., and J.V. Allen. 1969. Livestock production and profitability comparisons of various grazing systems, Texas Range Station. Tex. Agr. Exp. Sta. B-1089. 14 p.

Kothmann, M.M. 1968. The botanical composition and nutrient content of the diet of sheep grazing on poor condition pasture compared to good condition pastures. Ph.D. Diss., Texas A\&M Univ., College Station. 60 p.

Krebs, C.J. 1972. Ecology: The experimental analysis of distribution and abundance. Harper and Row, Pub. New York, Evanston, San Francisco, London. 694 p.

Langlands, J.P. 1967. Studies on the nutritive value of the diet selected by grazing sheep. II. Some source of error when sampling esophageally fistulated sheep at pasture. Anim. Prod. 9:167-176.

Laycock, W.A., and C.L. Batcheler. 1975. Comparison of distancemeasurement techniques for sampling tussock grassland species in New Zealand. J. Range Manage. 28:235-239.

Malechek, J.C. 1970. The botanical and nutritive composition of goat diets on lightly and heavily grazed ranges in the Edwards Plateau of Texas. Ph.D. Diss., Texas A\&M Univ., College Station. 61 p.

McCollum, J.M. 1972. The botanical composition of the diet of whitetailed deer. M.S. Thesis, Texas A\&M Univ., College Station. 51 p.

McMahan, C.A. 1964. Comparative food habits of deer and three classes of livestock. J. Wildl. Manage. 28:798-808.

Merrill, L.B., and V.A. Young. 1954. Results of grazing single classes of livestock in combination with several classes when stocking rates are constant. Tex. Agr. Exp. Sta. P.R. 1726. 6 p.

Oosting, H.J. 1956. The study of plant communities. W.H. Freeman and Co. $440 \mathrm{p}$.

Regelin, W.L., R.M. Bartman, D.W. Reichert, and P.H. Neil. 1977. The influence of supplemental feed on food habits of tame deer. USDA Forest Serv. Res. Note R.M. 316.4 p.

Reichert, D.W. 1972. Rearing and training deer for food habit studies. USDA Forest Serv. Res. Note R.M. 208. 7 p.

Taylor, C.A. 1972. The botanical composition of cattle diets on a 7-pasture high-intensity low-frequency grazing system. M.S. Thesis, Texas A\&M Univ., College Station. 60 p.

Taylor, C.A., and F.C. Bryant. 1977. A durable esophageal cannula for sheep and goats. J. Range Manage. 30:397-398.

Ullrey, D.E., W.G. Youatt, H.E. Johnson, L.D. Fay, and B.L. Bradley. 1967. Protein requirements of white-tailed deer fawns. J. Wildl. Manage. 31:679-685. 